
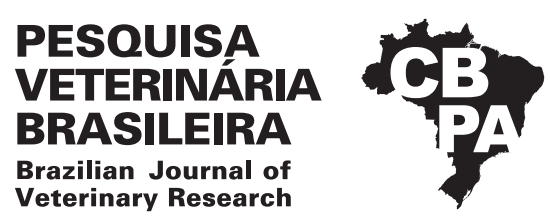

Pesq. Vet. Bras. 38(10):2012-2018, outubro 2018 DOI: $10.1590 / 1678-5150-P V B-5581$

Original Article

ISSN 0100-736X (Print)

ISSN 1678-5150 (Online)

\title{
Distribution of 5-methylcytosine and 5-hydroxymethylcytosine in bovine fetal tissue of the placenta $^{1}$
}

\author{
Anelise S. Mendonça ${ }^{2,3}$, Thiago F. Braga², Eduardo O. Melo², Margot A.N. Dode ${ }^{2}$ \\ and Maurício M. Franco ${ }^{2,3,4 *}$
}

\begin{abstract}
Mendonça A.S., Braga T.F., Melo E.O., Dode M.A.N. \& Franco M.M. 2018. Distribution of 5-methylcytosine and 5-hydroxymethylcytosine in bovine fetal tissue of the placenta. Pesquisa Veterinária Brasileira 38(10):2012-2018. Embrapa Recursos Genéticos e Biotecnologia, Parque Estação Biológica, Avenida W5 Norte (final), Cx. Postal 02372, Asa Norte, Brasília, DF 70770-917, Brazil. E-mail: mauricio.franco@embrapa.br

5-methylcytosine (5-mC) and 5-hydroxymethylcytosine (5-hmC) are modified cytosines found in mammals that are involved in the regulation of gene expression. The aim of this study was to characterize the global patterns of 5-mC and 5-hmC of the fetal placenta of Nellore cattle as well as blood and sperm as controls. 5-mC and 5-hmC levels were determined using MethylFlash Methylated/Hydroxymethylated DNA Quantification Kit, respectively. Placenta tissues showed lower levels of 5-mC and 5-hmC compared to sperm. The male cotyledon showed higher levels of 5-hmC than the female. For the first time, the levels of 5-mC and 5-hmC in Bos taurus indicus were characterized, which may contribute to our understanding of the mechanisms of epigenetic regulation in the placenta. The presence of 5-hmC in somatic tissues suggest that 5 -hmC has its own biological function and it is not only a byproduct from the oxidation of 5-mC. These results may be of interest in ARTs, especially in cloning in the diagnosis/prognosis of aberrant placentation and the viability of pregnancies.
\end{abstract}

INDEX TERMS: Methylation, hydroxymethylation, fetal tissue, placenta, epigenetics, cattle, physiology.

\begin{abstract}
RESUMO.- [Distribuição de 5-metilcitosina e 5-hidroximetilcitosina em placenta fetal bovina.] 5-metilcitosina (5-mC) e 5-hidroximetilcitosina (5-hmC) são citosinas modificadas encontradas nos mamíferos que estão envolvidas com a regulação da expressão gênica. 0 objetivo do presente estudo foi caracterizar os padrões globais de 5-mC e 5-hmC em placenta fetal de animais da raça Nelore, assim como em sangue e espermatozoides, usados como controles. Os níveis de 5-mC e 5-hmC foram determinados usando os kits MethylFlash Methylated/Hydroxymethylated
\end{abstract}

\footnotetext{
${ }^{1}$ Received on December 6, 2017.

Accepted for publication on December 13, 2017.

${ }^{2}$ Laboratório de Reprodução Animal, Embrapa Recursos Genéticos e Biotecnologia, Parque Estação Biológica, Avenida W5 Norte (final), Asa Norte, Brasília, DF 70770-917, Brazil. E-mails: thiagobraga86@gmail.com, eomelo@gmail.com, margot.dode@embrapa.br

${ }^{3}$ Faculdade de Medicina Veterinária, Universidade Federal de Uberlândia (UFU), Rua Ceará s/n, Umuarama, Uberlândia, MG 38400-902, Brazil. E-mail: anelise.mendonca@yahoo.com.br

${ }^{4}$ Instituto de Genética e Bioquímica, Universidade Federal de Uberlândia (UFU), Avenida Pará 1720, Umuarama, Uberlândia, MG 38400-902. *Corresponding author: mauricio.franco@embrapa.br
}

DNA Quantification, respectivamente. Tecidos placentários apresentaram menores níveis de 5-mC e 5-hmC quando comparados com espermatozoides. Cotilédones de machos apresentaram maiores níveis de 5-hmC do que os de fêmeas. Os níveis de 5-mC e 5-hmC em animais Bos taurus indicus foram caracterizados pela primeira vez, o que pode contribuir para o nosso conhecimento sobre a regulação dos mecanimos epigenéticos na placenta. A presença de $5-\mathrm{hmC}$ em tecidos somáticos sugerem que essa base pode ter sua própria função biológica, sendo não somente um sub-produto da oxidação da 5-mC. Esses resultados podem ser de interesse nas Tecnologias de Reprodução Assistida, especialmente na clonagem, no diagnóstico/prognóstico de placentação aberrante e viabilidade da progênie.

TERMOS DE INDEXAÇÃO: Metilcitosina, hidroximetilcitosina, placenta, feto, bovinos, fisiologia.

\section{INTRODUCTION}

Epigenetic marks are essential to the establishment of specific gene expression programs, and, in turn, cell differentiation and development. The first well-characterized epigenetic event 
occurring in DNA molecules was the addition of a methyl group on cytosine (5-mC), which is preferentially established at CpG dinucleotides in the mammalian genome (Branco et al. 2012). A group of enzymes called DNA methyltransferases (DNMTs) catalyzes this epigenetic modification (Li \& Liu 2011). DNA methylation is generally associated with epigenetic regulation in almost all biological processes, including development, growth and differentiation (Reik et al. 2001) and has important roles in the establishment of primordial germ cells (PGCs), gametogenesis and after fertilization (Reik 2007, Branco et al. 2012). Moreover, DNA methylation is involved in the establishment of some diseases, such as cancer (Farias et al. 2015).

DNA methylation is an epigenetic mark studied in several mammalian species, including cattle. Using different methodologies, the literature have been elucidated the characteristics of genome methylation in bovine, especially in placenta tissues. An interesting work explored the bovine methylome using methylated DNA immunoprecipitation combined with high-throughput sequencing (MeDIP-seq), comparing animals produced by somatic cell nuclear transfer (SCNT) technique with those produced with natural conception, in which the authors found higher methylation levels in gene body comparing to promotor in placenta tissues (Su et al. 2014). The literature has shown that placenta can be a quality marker for normal development during bovine pregnancy, considering DNA methylation pattern of specific genes. The insulin-like growth factor 2 (IGF-2) is an important modulator of placental and fetal growth (Gebert et al. 2006, Frost \& Moore 2010) and it is showed that this gene is hypermethylated in placenta from animals produced naturally comparing to placenta from calves produced by SCNT (Su et al. 2014). In placenta from cloned animals, the hypomethylation pattern of IGF2 gene is associated with overexpression, which is responsible for many of cloning problems, including large offspring syndrome (Yang et al. 2005).

In 1972, Penn et al. discovered 5-hydroxymethylcytosine (5-hmC), which was characterized as the sixth DNA base a few years later (Penn et al. 1972). 5-hmC is an epigenetic factor related to the DNA demethylation process (Bogdanovic et al. 2016) and is generated from the oxidation of 5-mC (hydroxylation) by a group of enzymes called Ten Eleven Translocation (TET) proteins (Tahiliani et al. 2009). These enzymes are $\alpha$-oxoglutarate dioxygenases and they are dependent to Fe (II) as a cofator. TETs utilize molecular oxygen to hydroxylate alkyl groups to hydroxymethyl functionalities via a radical-based mechanism (Loenarz \& Schofield 2009).

Although 5-hmC was discovered decades ago, its function remains relatively unknown. A question that must be elucidated is whether $5-\mathrm{hmC}$ is just an intermediate product of the DNA demethylation process or if $5-\mathrm{hmC}$ has a specific biological function. The association of 5-hmC with diseases, such as cancer (Orr et al. 2012), neurological (Kato \& Iwamoto 2014) and cardiovascular disorders (Barrick et al. 2009), stem cell renewal (Shukla et al. 2015), and gametogenesis and embryogenesis (Iqbal et al. 2011) has been studied.

5-hmC is present in many tissues and cell types. In humans, the tissues most enriched with 5-hmC are the brain, kidney, liver, colon and rectum, whereas the colon and rectum also have higher levels of 5-mC (Li \& Liu 2011). Nervous system cells of mice and humans are also enriched with 5-hmC (Li \& Liu
2011), especially Purkinje neurons (Kriaucionis \& Heintz 2009). In cattle, little is known about the frequency, distribution and function of 5-hmC. Its biological importance as an intermediate product of DNA demethylation as well as the importance of epigenetic reprogramming in gametogenesis and initial embryo development (Reik et al. 2001, Faulk \& Dolinoy 2014) justify studies that characterize the distribution of 5-hmC in bovine tissues strictly related to reproduction. The elucidation of these questions could support the improvement of the efficiency of assisted reproductive techniques (ARTs).

Overall, this study aimed to characterize the global patterns of 5-mC and 5-hmC in male and female bovine fetal placentas, using blood and sperm as controls.

\section{MATERIALS AND METHODS}

Animals. The placenta and blood of nineteen Nellore newborn calves (Bos taurus indicus) of both sexes (male $\mathrm{N}=11$, female $\mathrm{N}=10$ ) were collected. The semen of five bulls, which were submitted to three andrological evaluations and showed $\geq 70 \%$ sperm motility and a minimum of $70 \%$ morphologically normal cells were collected and used as controls.

The Ethics Committee of Embrapa Genetic Resources and Biotechnology (Protocol CEUA - Cenargen 004/2013) approved all procedures with animals.

Sample collection. Blood samples were collected from the jugular vein using a vacutainer system. Placenta tissues $\left(\sim 1 \mathrm{~cm}^{2}\right)$ were collected using a sterile scissor and tweezer. Samples from the following three different regions of the placenta were collected: 1) the cotyledon, the fetal side of the placentome, 2) the allantochorion membrane, and 3) the funiculus umbilicalis. All samples were collected immediately after birth.

Blood samples were stored at $-20^{\circ} \mathrm{C}$ and placenta tissues were stored at $-80^{\circ} \mathrm{C}$ until DNA extraction. One ejaculate from each bull was collected by electroejaculation. Sperm samples were stored in liquid nitrogen until DNA extraction.

DNA extraction. Genomic DNA from the blood, funiculus umbilicalis, cotyledon, and allantochorion samples was extracted using the QIAmp DNA Mini and Blood Mini Kit (Qiagen, Hilden, Germany) according to the manufacturer's protocol. DNA from sperm cells was extracted using a Salting Out protocol (Carvalho et al. 2012).

Global DNA methylation and hydroxymethylation. Genomic DNA from blood $(\mathrm{N}=19)$, funiculus umbilicalis $(\mathrm{N}=18)$, cotyledon $(\mathrm{N}=11)$, allantochorion $(\mathrm{N}=12)$ and spermatozoa $(\mathrm{N}=5)$ was submitted to global DNA methylation and hydroxymethylation analysis using the MethylFlash Methylated/Hydroxymethylated DNA Quantification Kit (Epigentek, Farmingdale/NY, USA) according to the manufacturer's protocol. The protocol used specific antibodies against methylated and hydroxymethylated cytosines. The results were analyzed according to a colorimetric signal and corrected using a standard curve with six dilutions of the positive control $(0,0.5,1.0,2.0,5.0$ and 10.0 $\mathrm{ng})$, both to 5-mC and 5-hmC. Samples and controls were run in duplicate.

Statistical analyses. The methylation pattern data were compared among experimental groups using ANOVA and Tukey's test or Kruskal-Wallis and Mann-Whitney U tests for data showing or not showing normality, respectively. All of the analyses were performed using Systat software version 10.2 (Inc., Richmond/CA, USA), and the results are presented as the mean \pm standard error of the mean (SEM). 


\section{RESULTS}

We determined the 5-hmC and 5-mC levels of DNA in extraembryonic tissues, allantochorion, cotyledon and funiculus umbilicalis and in blood and sperm as controls. The levels of 5-hmC, 5-mC and 5-hmC + 5-mC in the blood, allantochorion, cotyledon, funiculus umbilicalis and sperm are showed in Table 1 and are also represented in Figure 1. Sperm showed higher levels of 5-mC and 5-hmC comparing to blood and placenta tissues, whereas funiculus umbilicalis presented lower levels of 5-mC comparing to spermatozoa. The levels of 5-hmC did not differenciate among the placenta tissues.

We also compared the methylation and hydroxymethylation levels in blood, placenta (allantochorion + cotyledon), funiculus umbilicalis and sperm. The results are presented in Table 2 and Figure 2. The levels of 5-mC and 5-hmC in sperm were also higher comparing to blood and placenta, whereas funiculus umbilicalis presented higher levels of 5-mC than blood and higher levels of 5-hmC than blood and placenta tissues.

Considering that $5-\mathrm{hmC}$ is a byproduct of the $5-\mathrm{mC}$ oxidation, we also calculated and compared the $5-\mathrm{mC} / 5-\mathrm{hmC}$ ratio among the different tissues. The ratios in blood, allantochorion, cotyledon, funiculus umbilicalis and sperm were $4.75 \pm 0.86$, $3.24 \pm 5.04,7.63 \pm 2.79,4.89 \pm 0.90$ and $2.52 \pm 0.32$, respectively. There were no significant differences among tissues $(p=0.609)$. The data are also shown in Figure 3.

Table 1. 5-hydroxymethylcytosine (5-hmC) and 5-methylcytosine (5-mC) levels (mean \pm SEM) in blood, allantochorion, cotyledon, funiculus umbilicalis and sperm of Bos taurus indicus cattle

\begin{tabular}{|c|c|c|c|}
\hline Sample & $\begin{array}{c}\text { 5-hmC } \\
(\%)\end{array}$ & $\begin{array}{c}5-\mathrm{mC} \\
(\%)\end{array}$ & $\begin{array}{c}5-\mathrm{hmC}+5-\mathrm{mC} \\
(\%)\end{array}$ \\
\hline Blood (n=19) & $3.47 \pm 0.44$ & $12.68 \pm 1.55$ & $16.15 \pm 1.76$ \\
\hline $\begin{array}{l}\text { Allantochorion } \\
(\mathrm{n}=12)\end{array}$ & $2.86 \pm 0.10$ & $17.26 \pm 4.35$ & $20.11 \pm 3.01$ \\
\hline $\begin{array}{l}\text { Cotyledon } \\
(\mathrm{n}=11)\end{array}$ & $2.43 \pm 0.64$ & $12.94 \pm 1.65$ & $15.36 \pm 2.06$ \\
\hline $\begin{array}{l}\text { Funiculus } \\
\text { umbilicalis } \\
(n=18)\end{array}$ & $6.69 \pm 1.17$ & $22.64 \pm 2.99$ & $29.65 \pm 3.19$ \\
\hline Sperm $(n=5)$ & $14.35 \pm 1.25$ & $34.87 \pm 2.31$ & $49.22 \pm 3.98$ \\
\hline$p$ value & $<0.001$ & $<0.001$ & $<0.001$ \\
\hline
\end{tabular}

Table 2. 5-hydroxymethylcytosine (5-hmC) and 5-methylcytosine $(5-\mathrm{mC})$ levels (mean \pm SEM) in blood, placenta, funiculus umbilicalis and sperm of Bos taurus indicus cattle

\begin{tabular}{lccc}
\hline \multicolumn{1}{c}{ Sample } & $\begin{array}{c}5 \text {-hmC } \\
(\%)\end{array}$ & $\begin{array}{c}5 \text { - } \mathrm{mC} \\
(\%)\end{array}$ & $\begin{array}{c}5 \text {-hmC }+5 \text {-mC } \\
(\%)\end{array}$ \\
\hline Blood $(\mathrm{n}=19)$ & $3.47 \pm 0.44$ & $12.68 \pm 1.55$ & $16.15 \pm 1.76$ \\
Placenta $(\mathrm{n}=11)$ & $2.63 \pm 0.82$ & $15.19 \pm 3.46$ & $17.82 \pm 2.37$ \\
Funiculus & $6.69 \pm 1.17$ & $22.64 \pm 2.99$ & $29.65 \pm 3.19$ \\
umbilicalis & & & \\
$(\mathrm{n}=18)$ & & & \\
Sperm $(\mathrm{n}=5)$ & $14.35 \pm 1.25$ & $34.87 \pm 2.31$ & $49.22 \pm 3.98$ \\
$p$ value & $<0.001$ & $<0.001$ & $<0.001$
\end{tabular}

We also compared methylation and hydroxymethylation levels between genders. The data are presented in Table 3 and in the Figure 4 . The vast majority of analyses did not present differences in methylation levels between males and females. However, male animals presented high levels of $5-\mathrm{hmC}$ in the cotyledon compared to females $(p=0.018)$.

\section{DISCUSSION}

It is known that $5-\mathrm{mC}$ is an epigenetic process that mediates various cellular and molecular events, such as gene regulation (Moarii et al. 2015), genomic imprinting (Bretz et al. 2015), X chromosome inactivation (Gentilini et al. 2015) and cancer

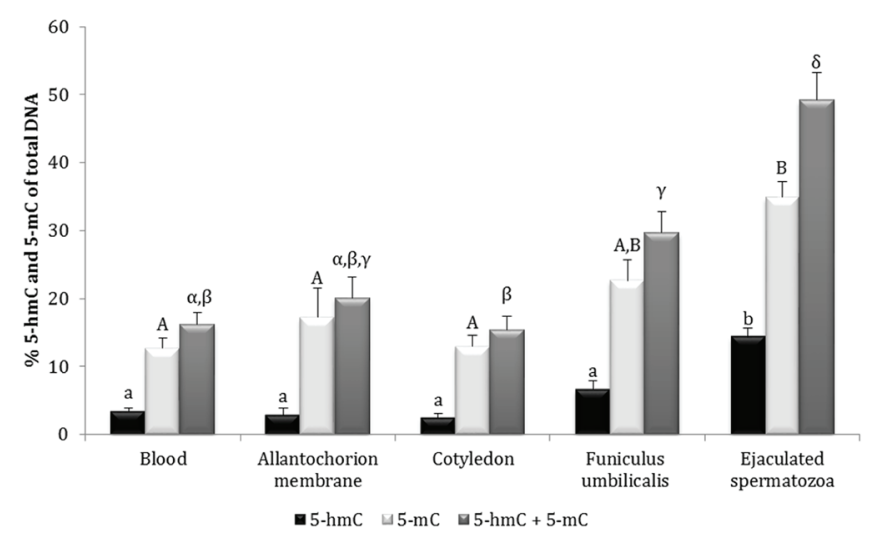

Fig.1. Levels of 5-hmC and 5-mC in the blood, placenta tissues and sperm of Bos taurus indicus cattle. 5-hydroxymethylcytosine (5-hmC), 5-methylcytosine (5-mC) and 5-hmC $+5-\mathrm{mC}$ are represented as bars in each of the analyzed tissues. Data are shown as the mean \pm SEM. Lower case (5-hmC), capital letters (5-mC) and Greek letters $(5-\mathrm{hmC}+5-\mathrm{mC})$ were used to show the differences among tissues. Different letters represent different levels of methylated/ hydroxymethylated cytosine among tissues $(p<0.05)$.

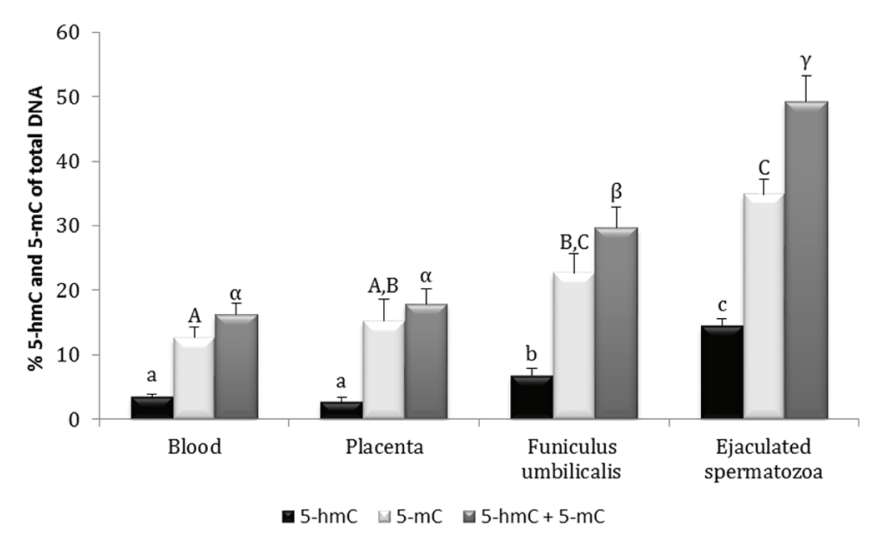

Fig.2. Levels of 5-hmC and 5-mC in blood, extraembryonic tissues and sperm of Bos taurus indicus cattle. 5-Hydroxymethylcytosine (5-hmC), 5-methylcytosine (5-mC) and 5-hmC + 5-mC are represented as bars in each of the analyzed tissues. Data are shown as the mean \pm SEM. Lower case (5-hmC), capital letters (5-mC) and Greek letters $(5-\mathrm{hmC}+5-\mathrm{mC})$ were used to show the differences among tissues. Different letters represent different levels of methylated/ hydroxymethylated cytosine among tissues $(p<0.05)$. 
Table 3. 5-hydroxymethylcytosine (5-hmC) and 5-methylcytosine (5-mC) levels (mean \pm SEM) in blood, allantochorion, cotyledon and funiculus umbilicalis of Bos taurus indicus cattle according to gender

\begin{tabular}{|c|c|c|c|c|c|c|}
\hline \multirow{2}{*}{ Sample } & \multicolumn{3}{|c|}{ Male } & \multicolumn{3}{|c|}{ Female } \\
\hline & 5-hmC (\%) & 5-mC (\%) & 5-hmC + 5-mC (\%) & 5-hmC (\%) & $5-\mathrm{mC}(\%)$ & $5-\mathrm{hmC}+5-\mathrm{mC}(\%)$ \\
\hline Blood $(n=19)$ & $2.67 \pm 0.40$ & $12.77 \pm 2.29$ & $15.44 \pm 2.30$ & $4.37 \pm 0.73$ & $12.57 \pm 2.20$ & $16.94 \pm 2.82$ \\
\hline Allantochorion $(n=12)$ & $2.99 \pm 1.54$ & $10.71 \pm 2.99$ & $13.21 \pm 2.13$ & $2.72 \pm 1.45$ & $23.80 \pm 7.56$ & $26.06 \pm 7.57$ \\
\hline Cotyledon $(n=11)$ & $4.15 \pm 0.74$ & $12.99 \pm 1.86$ & $17.15 \pm 2.52$ & $0.98 \pm 0.46$ & $12.89 \pm 2.78$ & $13.87 \pm 3.00$ \\
\hline Funiculus umbilicalis $(\mathrm{n}=18)$ & $7.91 \pm 2.10$ & $24.13 \pm 4.31$ & $31.25 \pm 4.47$ & $5.32 \pm 0.61$ & $20.78 \pm 4.25$ & $26.10 \pm 4.55$ \\
\hline
\end{tabular}

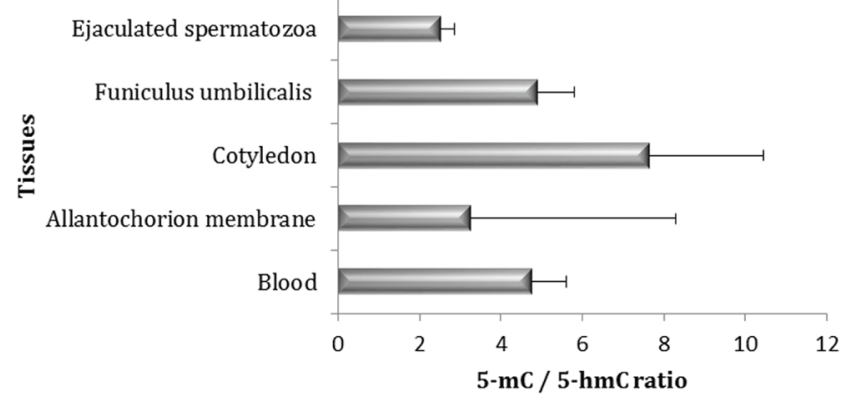

Fig.3. 5-mC/5-hmC ratios in blood, allantochorion, cotyledon, funiculus umbilicalis and sperm of Bos taurus indicus cattle. Data are shown as the mean \pm SEM. Bars indicate the ratio of 5-methylcytosine/5-hydroxymethylcytosine (5-mC/5-hmC) for the different tissues.

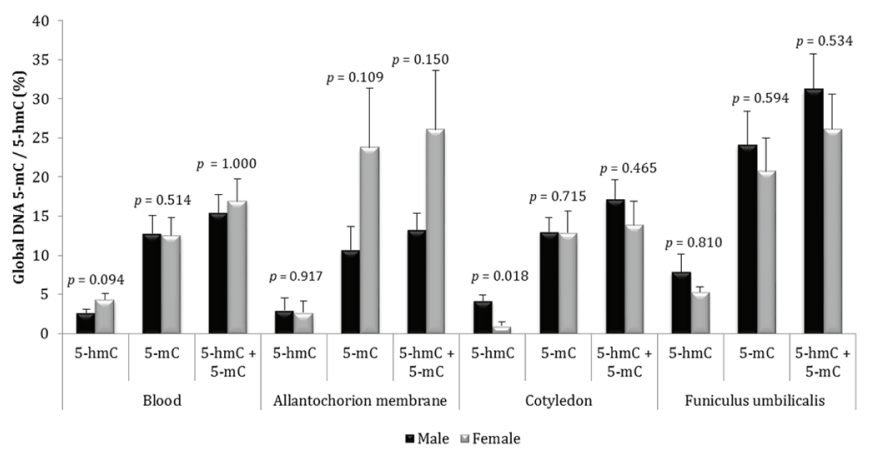

Fig.4. Levels of 5-hmC, 5-mC and 5-hmC $+5-\mathrm{mC}$ in blood and embryonic tissues by gender. Data of 5-hydroxymehyltcytosine (5-hmC), 5-methycytosine (5-mC) and 5-hmC + 5-mC are shown as the mean \pm SEM for each gender. Different letters represent different levels of methylated and hydroxymethylated cytosine between genders $(p<0.05)$.

development (Rauscher et al. 2015). Because of the importance of 5-mC in diseases, development and reproduction, it has been the focus of research in many scientific areas.

More recently, another cytosine modification has gained importance in the epigenetic context. $5-\mathrm{hmC}$ is present in the nervous system, especially in Purkinje cells in mice (Kriaucionis \& Heintz 2009) and human ESCs (Szulwach et al. 2011) and oocytes (Santos et al. 2013). TET enzymes convert 5-mC to 5-hmC (Tahiliani et al. 2009) in the process of DNA demethylation. It is important in the context of mammalian reproduction, as waves of demethylation occur during initial embryonic development (Oswald et al. 2000) and during the proliferation and migration of the primordial germ cells (Seisenberger et al. 2012).

Although bisulfite-based sequencing techniques (BS-seq) are more robust in evaluating methylation patterns at the single-base level in the genome, these techniques are expensive, time-consuming and are not able to distinguish 5-mC from 5-hmC (Jin et al. 2010), overestimating 5-mC levels due the presence of 5-hmC (Matsubara et al. 2015). We believe that these techniques are essential to precisely characterize the distribution of patterns of methylation across the different regions of the genome, as a gene promoter, intra- and intergenic regions, exons, and introns. There are techniques able to differentiate $5-\mathrm{mC}$ from $5-\mathrm{hmC}$, as hydroxymethylation and methylation-sensitive tag sequencing (HMST-Seq; McGraw et al. 2013) and colorimentric techniques. Simpler, cheaper and faster techniques can be very useful and essential in the routine of laboratories to monitor the development and adaptation of protocols and diagnosis. In this sense, ELISA-based techniques to quantify global methylation and hydroxymethylation are good options for these purposes. In this study, we characterized the 5-mC and 5-hmC levels in placenta tissues (allantochorion membrane, cotyledon and funiculus umbilicalis) of Nellore newborn animals using a colorimetric ELISA methodology, since it is known that placenta presents different methylation patterns in some specific genes comparing to somatic tissues (Nahar et al. 2015). We used blood and ejaculated sperm as controls. Blood was used as somatic tissue due to it's easily way to be collected at the same moment as placenta, whereas sperm was chosen because it is highly specialized and highly methylated cells (Kobayashi et al. 2012), which was important as one more methylated control.

Placenta is formed from extraembryonary membranes, which are originated from endoderm, mesoderm and trophoectoderm. Trophoectoderm cells are strictly related to the maternal recognition of pregnancy and embryo development. An aberrant pattern of 5-mC and 5-hmC in extraembryonic tissues can cause placentation problems, which may be responsible for the inefficient SCNT technique in mammals (Salilew-Wondim et al. 2013). We found that both, the allantochorion and cotyledon showed lower levels of 5-mC and 5-hmC compared to sperm (Fig.1 and 2). The allantochorion and cotyledon are defined as extraembryonic tissues, which develop from the trophectoderm (TE) cells (Latendresse \& Founds 2015). Overall, placenta tissues present lower levels of DNA methylation compared to somatic tissues in humans and mice (Fuke et al. 2004, Hon et al. 2013). 
Moreover, hydroxymethylation was slightly higher in the inner cell mass (ICM) than in the TE in these two species (Ruzov et al. 2011). Using the same methodology that we used in this study, low levels of 5-mC and 5-hmC were also found in human placenta $(\sim 0.6 \%$ and $0.05 \%)$ compared to the rectum $(\sim 1.0 \%$ and $0.5 \%)$, colon $(\sim 1.5 \%$ and $0.4 \%)$ and brain $(\sim 0.9 \%$ and $0.7 \%)$, respectively (Li \& Liu 2011$)$. The majority of studies show the placenta with lower levels of DNA methylation compared to somatic tissues (Fuke et al. 2004, Hon et al. 2013), different from what we found in this study with bovine tissues compared with blood. These differences may be due to the different species studied, as cows, mice and humans are phylogenetically distant from each other. Monkeys presented approximately 30\% global DNA methylation in the blood (Pheiffer et al. 2014), similarly to what is found in human funiculus umbilicalis blood (Guerrero-Preston et al. 2010).

Lower levels of DNA methylation in the placenta may be expected. As tissues with metastatic tumors, the placenta has particular features: rapid proliferation, invasiveness and angiogenesis (Van Dijk et al. 2012, Novakovic \& Saffery 2013, Rousseaux et al. 2013). The hypomethylated status is probably an evolutionary advantage in temporary tissues, especially in the placenta, in which growth is regulated by pregnancy hormones (Schroeder et al. 2015).

Similar to the placenta, the funiculus umbilicalis is considered an extraembryonic tissue, formed by the extraembryonic mesoderm, which connects the fetus and mother through the placenta during pregnancy (Corrao et al. 2013). In this study, the funiculus umbilicalis showed the same levels of 5-mC compared to the placenta $(p=0.114)$ and higher levels compared to blood ( $p=0.025) .5$-hmC levels in the funiculus umbilicalis were higher than in the placenta $(p=0.002)$ and blood $(p=0.025$; Fig.2). The literature does not extensively describe the levels of DNA methylation in the funiculus umbilicalis in any species. Our study is one of the first to evaluate the levels of 5-mC and 5-hmC in such extraembryonic tissues. The correct pattern of DNA methylation in placenta is probably related to normal pregnancy and healthy newborn animals (Zhang et al. 2014). The literature has shown that almost all cloned bovine animals show a hypertrophied funiculus umbilicalis, which is strictly related to high mortality rates (Wells et al. 1999). It is important to characterize the physiological levels of 5-mC and 5-hmC in different extraembryonic tissues to subsidize the identification of possible problems in animals produced by ARTs, especially in cloning.

In this study, we used the 5-mC and 5-hmC levels of ejaculated sperm cells as a control because they are highly methylated and specialized cells. We found higher levels of 5-mC ( $\sim 35 \%)$ and 5-hmC ( $14 \%)$ in spermatozoa compared to the other analyzed tissues (Fig.1 and 2). Our results are in accordance with literature data using a murine model in which sperm have higher levels of global DNA methylation than oocytes, embryos in the early stage of development and somatic tissues (Kobayashi et al. 2012). High levels of DNA methylation are also found in sperm from mice (79.1\%) compared to prospermatogonia from 16.5-day embryos (30.1\%), which indicated that the hypermethylated status found in differentiated sperm samples is the result of an extensive process of epigenetic reprogramming in spermatogenesis (Kubo et al. 2015).
5-Hydroxymethylation is also a parameter used to epigenetically characterize the sperm. One possible reason why 5 -hmC was higher in the sperm than in the tissues we analyzed is the accumulation of 5-hmC that is necessary in the spermatozoa. Immediately after fertilization, an active DNA demethylation process occurs in the paternal genome (Faulk \& Dolinoy 2014), showing an increase of 5-hmC in the male pronucleus after fertilization (Gu et al. 2011, Iqbal et al. 2011) with a concomitant increase in TET3 mRNA (Gu et al. 2011). Thus, this initial 5-hmC accumulation in the sperm cells may be related to the active DNA demethylation process that occurs in the paternal genome after fertilization.

An interesting result in our study was the low levels of hydroxymethylation in the female cotyledon than the male $(p=0.018)$. Although any other difference between the sexes was not observed in this study, the difference found in cotyledon tissue may be a vestige of this embryonic difference. Bogomazova et al. (2014) also showed that the depletion of 5-hmC on the X chromosome indicated the process of X chromosome inactivation. As the cotyledon is an extraembryonic tissue, its decreasing levels of hydroxymethylation in females can be a trace of this embryonic event that occurs in all female mammals to compensate for the $\mathrm{X}$ dosage.

\section{CONCLUSIONS}

Our study showed that global methylation and hydroxymethylation patterns are different depending on the tissue and gender.

The presence of 5-hmC in somatic tissues may suggest that 5-hmC has its own biological function and it is not only a byproduct generated from the oxidation of 5-mC. For the first time, we characterized the levels of 5-mC and 5-hmC in Bos taurus indicus placenta tissues, which can be a useful source of information for studies with ART in humans and livestock, supporting studies related to the collateral effects of hormonal treatments or in vitro manipulations.

These results may be used as control for studies evaluating placenta from animals produced by ARTs, contributing to cloning by SCNT by understanding the non-physiological epigenetic profile in aberrant SCNT placenta.

Conflict of interest statement.- The authors have no competing interests.

Acknowledgments.- The work was supported by Brazilian Agricultural Research Corporation and Coordination for the Improvement of Higher Education Personnel (CAPES).

\section{REFERENCES}

Barrick C.J., Roberts R.B., Rojas M., Rajamannan N.M., Suitt C.B., O’Brien K.D., Smyth S.S. \& Threadgill D.W. 2009. Reduced EGFR causes abnormal valvular differentiation leading to calcific aortic stenosis and left ventricular hypertrophy in C57BL/6J but not 129S1/SvImJ mice. Am. J. Physiol.-Heart Circ. Physiol. 297(1):H65-H75. <http://dx.doi.org/10.1152/ ajpheart.00866.2008> <PMid:19448146>

Bogdanovic O., Smits A.H., de la Calle Mustienes E., Tena J.J., Ford E., Williams R., Senanayake U., Schultz M.D., Hontelez S., Van Kruijsbergen I., Rayon T., Gnerlich F., Carell T., Veenstra G.J.C., Manzanares M., Sauka-Spengler T., Ecker J.R., Vermeulen M., Gómez-Skarmeta J.L. \& Lister R. 2016. Active DNA demethylation at enhancers during the vertebrate phylotypic period. Nat. Genet. 48(4):417-426. <http://dx.doi.org/10.1038/ng.3522> <PMid:26928226> 
Bogomazova A.N., Lagarkova M.A., Panova A.V., Nekrasov E.D. \& Kiselev S.L. 2014. Reactivation of capital HA, Cyrillic chromosome upon reprogramming leads to changes in the replication pattern and $5 \mathrm{hmC}$ accumulation. Chromosoma 123:117-128. <http://dx.doi.org/10.1007/s00412-0130433-x><PMid:23982752>

Branco M.R., Ficz G. \& Reik W. 2012. Uncovering the role of 5-hydroxymethylcytosine in the epigenome. Nat. Rev. Genet.13(1):7-13. <http://dx.doi.org/10.1038/ nrg3080><PMid:22083101>

Bretz C.L., Langohr I.M., Lee S. \& Kim J. 2015. Epigenetic instability at imprinting control regions in a Kras-induced T-cell neoplasm. Epigenetics 10(12):1111-1120. <http://dx.doi.org/10.1080/15592294.2015.11106 72><PMid:26507119>

Carvalho J.O., Michalczechen-Lacerda V.A., Sartori R., Rodrigues F.C., Bravim O., Franco M.M. \& Dode M.A. 2012. The methylation patterns of the IGF2 and IGF2R genes in bovine spermatozoa are not affected by flow-cytometric sex sorting. Mol. Reprod. Develop. 79(2):77-84. <http://dx.doi.org/10.1002/ $\operatorname{mrd} .21410><$ PMid:22128039>

Corrao S., La Rocca G., Lo Iacono M., Corsello T., Farina F. \& Anzalone R. 2013. Umbilical cord revisited: from Wharton's jelly myofibroblasts to mesenchymal stem cells. Histol. Histopathol. 28(10):1235-1244. <PMid:23595555>

Farias N., Ho N., Butler S., Delaney L., Morrison J., Shahrzad S. \& Coomber B.L. 2015. The effects of folic acid on global DNA methylation and colonosphere formation in colon cancer cell lines. J. Nutr. Biochem. 26(8):818-826. <http://dx.doi.org/10.1016/j.jnutbio.2015.02.002> <PMid:25804133>

Faulk C. \& Dolinoy D.C. 2014. Timing is everything. Epigenetics 6(7):791-797. <http://dx.doi.org/10.4161/epi.6.7.16209> <PMid:21636976>

Frost J.M. \& Moore G.E. 2010. The importance of imprinting in the human placenta. PLoS Gen. 6(7):e1001015. <http://dx.doi.org/10.1371/journal. pgen.1001015><PMid:20617174>

Fuke C., Shimabukuro M., Petronis A., Sugimoto J., Oda T., Miura K., Miyazaki T., Ogura C., Okazaki Y. \& Jinno Y. 2004. Age related changes in 5-methylcytosine content in human peripheral leukocytes and placentas: an HPLC-based study. Ann. Hum. Genet. 68(Pt 3):196-204.<http://dx.doi. org/10.1046/j.1529-8817.2004.00081.x><PMid:15180700>

Gebert C., Wrenzycki C., Herrmann D., Gröger D., Reinhardt R., Hajkova P., Lucas-Hahn A., Carnwath J., Lehrach H. \& Niemann H. 2006. The bovine IGF2 gene is differentially methylated in oocyte and sperm DNA. Genomics 88(2):222-229. <http://dx.doi.org/10.1016/j.ygeno.2006.03.011> $<$ PMid:16644179>

Gentilini D., Garagnani P., Pisoni S., Bacalini M.G., Calzari L., Mari D., Vitale G., Franceschi C. \& Di Blasio A.M. 2015. Stochastic epigenetic mutations (DNA methylation) increase exponentially in human aging and correlate with $\mathrm{X}$ chromosome inactivation skewing in females. Aging 7(8):568-578. <http://dx.doi.org/10.18632/aging.100792> <PMid:26342808>

Gu T.-P., Guo F., Yang H., Wu H.-P., Xu G.-F., Liu W., Xie Z.-G., Shi L., He X., Jin S., Iqbal K., Shi Y.G., Deng Z., Szabó P.E., Pfeifer G.P., Li J. \& Xu G.-L. 2011. The role of Tet3 DNA dioxygenase in epigenetic reprogramming by oocytes. Nature 477(7366):606-610. <http://dx.doi.org/10.1038/nature10443> <PMid:21892189>

Guerrero-Preston R., Goldman L.R., Brebi-Mieville P., Ili-Gangas C., LeBron C., Witter F.R., Apelberg B.J., Hernández-Roystacher M., Jaffe A., Halden R.U. \& Sidransky D. 2010. Global DNA hypomethylation is associated with in utero exposure to cotinine and perfluorinated alkyl compounds. Epigenetics 5(6):539-546. <http://dx.doi.org/10.4161/epi.5.6.12378> <PMid:20523118>

Hon G.C., Rajagopal N., Shen Y., McCleary D.F., Yue F., Dang M.D. \& Ren B. 2013. Epigenetic memory at embryonic enhancers identified in DNA methylation maps from adult mouse tissues. Nat. Genet. 45(10):1198-1206. <http:// dx.doi.org/10.1038/ng.2746><PMid:23995138>

Iqbal K., Jin S.G., Pfeifer G.P. \& Szabó P.E. 2011. Reprogramming of the paternal genome upon fertilization involves genome-wide oxidation of 5-methylcytosine. Proc. Natl Acad. Sci. USA 108(9):3642-3647. <http:// dx.doi.org/10.1073/pnas.1014033108><PMid:21321204>

Jin S.G., Kadam S. \& Pfeifer G.P. 2010. Examination of the specificity of DNA methylation profiling techniques towards 5-methylcytosine and 5-hydroxymethylcytosine. Nucleic. Acids Res. 38(11):e125. <http://dx.doi. org/10.1093/nar/gkq223><PMid:20371518>

Kato T. \& Iwamoto K. 2014. Comprehensive DNA methylation and hydroxymethylation analysis in the human brain and its implication in mental disorders. Neuropharmacology 80:133-139. <http://dx.doi. org/10.1016/j.neuropharm.2013.12.019><PMid:24389572>

Kobayashi H., Sakurai T., Imai M., Takahashi N., Fukuda A., Yayoi O., Sato S., Nakabayashi K., Hata K., Sotomaru Y., Suzuki Y. \& Kono T. 2012. Contribution of intragenic DNA methylation in mouse gametic DNA methylomes to establish oocyte-specific heritable marks. PLoS Genet. 8(1):e1002440. <http://dx.doi.org/10.1371/journal.pgen.1002440><PMid:22242016>

Kriaucionis S. \& Heintz N. 2009. The nuclear DNA base 5-hydroxymethylcytosine is present in Purkinje neurons and the brain. Science 324(5929):929-930. <http://dx.doi.org/10.1126/science.1169786><PMid:19372393>

Kubo N., Toh H., Shirane K., Shirakawa T., Kobayashi H., Sato T., Sone H., Sato Y., Tomizawa S., Tsurusaki Y., Shibata H., Saitsu H., Suzuki Y., Matsumoto N., Suyama M., Kono T., Ohbo K. \& Sasaki H. 2015. DNA methylation and gene expression dynamics during spermatogonial stem cell differentiation in the early postnatal mouse testis. BMC Genomics 16(1):624. <http://dx.doi. org/10.1186/s12864-015-1833-5><PMid:26290333>

Latendresse G. \& Founds S. 2015. The Fascinating and Complex Role of the Placenta in Pregnancy and Fetal Well-being. J. Midwifery Womens Health 60(4):360-370.<http://dx.doi.org/10.1111/jmwh.12344><PMid:26255798>

Li W. \& Liu M. 2011. Distribution of 5-hydroxymethylcytosine in different human tissues. J. Nucleic Acids 2011:870726. <http://dx.doi. org/10.4061/2011/870726> <PMid:21772996>

Loenarz C. \& Schofield C.J. 2009. Oxygenase catalyzed 5-methylcytosine hydroxylation. Chem. Biol. 16(6):580-583.<http://dx.doi.org/10.1016/j. chembiol.2009.06.002><PMid:19549596>

Matsubara K., Kagami M., Nakabayashi K., Hata K., Fukami M., Ogata T. \& Yamazawa K. 2015. Exploration of hydroxymethylation in Kagami-Ogata syndrome caused by hypermethylation of imprinting control regions. Clin. Epigenetics 7(1):90. <http://dx.doi.org/10.1186/s13148-015-0124-y> $<$ PMid:26322139>

McGraw S., Shojaei Saadi H.A. \& Robert C. 2013. Meeting the methodological challenges in molecular mapping of the embryonic epigenome. Mol. Hum. Reprod. 19(12):809-827. <http://dx.doi.org/10.1093/molehr/gat046> <PMid:23783346>

Moarii M., Boeva V., Vert J.P. \& Reyal F. 2015. Changes in correlation between promoter methylation and gene expression in cancer. BMC Genomics 16(1):873. <http://dx.doi.org/10.1186/s12864-015-1994-2> <PMid:26510534>

Nahar M.S., Liao C., Kannan K., Harris C. \& Dolinoy D.C. 2015. In utero bisphenol A concentration, metabolism, and global DNA methylation across matched placenta, kidney, and liver in the human fetus. Chemosphere 124:54-60. <http://dx.doi.org/10.1016/j.chemosphere.2014.10.071><PMid:25434263>

Novakovic B. \& Saffery R. 2013. Placental pseudo-malignancy from a DNA methylation perspective: unanswered questions and future directions. Front. Genet. 4:285. <http://dx.doi.org/10.3389/fgene.2013.00285> <PMid:24368911>

Orr B.A., Haffner M.C., Nelson W.G., Yegnasubramanian S. \& Eberhart C.G. 2012. Decreased 5-hydroxymethylcytosine is associated with neural progenitor phenotype in normal brain and shorter survival in malignant glioma. PLoS One 7(7):e41036. <http://dx.doi.org/10.1371/journal. pone.0041036><PMid:22829908>

Oswald J., Engemann S., Lane N., Mayer W., Olek A., Fundele R., Dean W., Reik W. \& Walter J. 2000. Active demethylation of the paternal genome in the 
mouse zygote. Curr. Biol. 10(8):475-478. <http://dx.doi.org/10.1016/ S0960-9822(00)00448-6> <PMid:10801417>

Penn N.W., Suwalski R., O’Riley C., Bojanowski K. \& Yura R. 1972. The presence of 5-hydroxymethylcytosine in animal deoxyribonucleic acid. Biochem. J. 126(4):781-790. <http://dx.doi.org/10.1042/bj1260781><PMid:4538516>

Pheiffer C., Dias S., Muller C. \& Louw J. 2014. Decreased global DNA methylation in the white blood cells of high fat diet fed vervet monkeys (Chlorocebus aethiops). J. Physiol. Biochem. 70(3):725-733.<http://dx.doi.org/10.1007/ s13105-014-0341-4> <PMid:24943073>

Rauscher G.H., Kresovich J.K., Poulin M., Yan L., Macias V., Mahmoud A.M., AlAlem U., Kajdacsy-Balla A., Wiley E.L., Tonetti D. \& Ehrlich M. 2015. Exploring DNA methylation changes in promoter, intragenic, and intergenic regions as early and late events in breast cancer formation. BMC Cancer 15(1):816. <http://dx.doi.org/10.1186/s12885-015-1777-9> <PMid:26510686>

Reik W. 2007. Stability and flexibility of epigenetic gene regulation in mammalian development. Nature 447(7143):425-432. <http://dx.doi. org/10.1038/nature05918> <PMid:17522676>

Reik W., Dean W. \& Walter J. 2001. Epigenetic reprogramming in mammalian development. Science 293(5532):1089-1093. <http://dx.doi.org/10.1126/ science.1063443> <PMid:11498579>

Rousseaux S., Debernardi A., Jacquiau B., Vitte A.-L., Vesin A., Nagy-Mignotte H., Moro-Sibilot D., Brichon P.-Y., Lantuejoul S., Hainaut P., Laffaire J., de Reynies A., Beer D.G., Timsit J.-F., Brambilla C., Brambilla E. \& Khochbin S. 2013. Ectopic activation of germline and placental genes identifies aggressive metastasis-prone lung cancers. Sci. Transl. Med. 5(186):186ra66. <http://dx.doi.org/10.1126/scitranslmed.3005723><PMid:23698379>

Ruzov A., Tsenkina Y., Serio A., Dudnakova T., Fletcher J., Bai Y., Chebotareva T., Pells S., Hannoun Z., Sullivan G., Chandran S., Hay D.C., Bradley M., Wilmut I. \& De Sousa P. 2011. Lineage-specific distribution of high levels of genomic 5-hydroxymethylcytosine in mammalian development. Cell Res. 21(9):13321342. <http://dx.doi.org/10.1038/cr.2011.113> <PMid:21747414>

Salilew-Wondim D., Tesfaye D., Hossain M., Held E., Rings F., Tholen E., Looft C., Cinar U., Schellander K. \& Hoelker M. 2013. Aberrant placenta gene expression pattern in bovine pregnancies established after transfer of cloned or in vitro produced embryos. Physiol. Genomics 45(1):28-46. <http:// dx.doi.org/10.1152/physiolgenomics.00076.2012><PMid:23092953>

Santos F., Peat J., Burgess H., Rada C., Reik W. \& Dean W. 2013. Active demethylation in mouse zygotes involves cytosine deamination and base excision repair. Epigenetics Chromatin 6(1):39. <http://dx.doi. org/10.1186/1756-8935-6-39> <PMid:24279473>

Schroeder D.I., Jayashankar K., Douglas K.C., Thirkill T.L., York D., Dickinson P.J., Williams L.E., Samollow P.B., Ross P.J., Bannasch D.L., Douglas G.C. \&
LaSalle J. 2015. Early developmental and evolutionary origins of gene body DNA methylation patterns in mammalian placentas. PLoS Genet 11(8):e1005442. <http://dx.doi.org/10.1371/journal.pgen.1005442> <PMid:26241857>

Seisenberger S., Andrews S., Krueger F., Arand J., Walter J., Santos F., Popp C., Thienpont B., Dean W. \& Reik W. 2012. The dynamics of genome-wide DNA methylation reprogramming in mouse primordial germ cells. Mol. Cell 48(6):849-862. <http://dx.doi.org/10.1016/j.molcel.2012.11.001> $<$ PMid:23219530>

Shukla A., Sehgal M. \& Singh T.R. 2015. Hydroxymethylation and its potential implication in DNA repair system: a review and future perspectives. Gene 564(2):109-118. <http://dx.doi.org/10.1016/j.gene.2015.03.075> $<$ PMid:25862923>

Su L., Wang Y., Xing X., Liu J. \& Zhang Y. 2014. Genome-wide analysis of DNA methylation in bovine placentas. BMC Genomics 15:12.

Szulwach K.E., Li X.K., Li Y.J., Song C.X., Han J.W., Kim S., Namburi S., Hermetz K., Kim J.J., Rudd M.K., Yoon Y-S., Ren B., He C. \& Jin P. 2011. Integrating 5-hydroxymethylcytosine into the epigenomic landscape of human embryonic stem cells. PLoS Genet. 7:e1002154.

Tahiliani M., Koh K.P., Shen Y., Pastor W.A., Bandukwala H., Brudno Y., Agarwal S., Iyer L.M., Liu D.R., Aravind L. \& Rao A. 2009. Conversion of 5-methylcytosine to 5-hydroxymethylcytosine in mammalian DNA by MLL partner TET1. Science 324(5929):930-935. <http://dx.doi.org/10.1126/ science.1170116><PMid:19372391>

Van Dijk M., Visser A., Posthuma J., Poutsma A. \& Oudejans C.B. 2012. Naturally occurring variation in trophoblast invasion as a source of novel (epigenetic) biomarkers. Front. Genet. 3:22.<http://dx.doi.org/10.3389/ fgene.2012.00022><PMid:22363344>

Wells D.N., Misica P.M. \& Tervit H.R. 1999. Production of cloned calves following nuclear transfer with cultured adult mural granulosa cells. Biol. Reprod. 60(4):996-1005.<http://dx.doi.org/10.1095/biolreprod60.4.996> <PMid:10084977>

Yang L., Chavatte-Palmer P., Kubota C., O'Neill M., Hoagland T., Renard J.P., Taneja M., Yang X.Z. \& Tian X.C. 2005. Expression of imprinted genes is aberrant in deceased newborn cloned calves and relatively normal in surviving adult clones. Mol. Reprod. Dev. 71(4):431-438. <http://dx.doi. org/10.1002/mrd.20311><PMid:15895469>

Zhang X., Wang D., Han Y., Duan F., Lv Q. \& Li Z. 2014. Altered imprinted gene expression and methylation patterns in mid-gestation aborted cloned porcine fetuses and placentas. J. Assist. Reprod. Genet. 31(11):1511-1517. <http://dx.doi.org/10.1007/s10815-014-0320-2> <PMid:25172095> 